\title{
Lithostratigraphy and planktonic foraminifera of the uppermost Cretaceous-Upper Palaeocene strata of the Tavas nappe of the Lycian nappes (SW Turkey)
}

\author{
Bilal Sarı \\ Dokuz Eylül University, Faculty of Engineering, Department of Geological Engineering, Tınaztepe Campus, 35160, Buca-Izmir, Turkey; (bilal.sari@deu.edu.tr) \\ doi: $10.4154 / g c .2017 .14$

Article history:

Manuscript received June 06, 2017

Revised manuscript accepted October 04, 2017

Available online October 31, 2017

\begin{abstract}
The Lycian nappes lying on top of the para-autochthonous metamorphosed Menderes and unmetamorphosed Bey Dağları successions in SW Anatolia belong to the Tauride segment of the Anatolide-Tauride Block. The Tavas nappe is one of several nappe slices of the Lycian nappes and forms structurally the lowermost tectono-stratigraphic unit. The upper part of the Tavas nappe succession is represented by planktonic foraminifera-bearing uppermost Cretaceous cherty micritic limestones and calciturbidites of the Babadağ Formation and Lower Palaeogene micritic limestones and calciclastic rocks of the Faralya Formation in the study area. Lithostratigraphic characteristics and planktonic foraminiferal assemblages of the two formations in the Bozburun hill locality (S of Köyceğiz) are documented for the first time in three stratigraphic sections in this study. The uppermost part of the Babadağ Formation mainly comprises of alternating calciclastic and micritic limestones, which include diverse planktonic foraminiferal assemblages of mainly keeled morphotypes. The presence of Racemiguembelina fructicosa and Abathomphalus mayaroensis within the assemblages indicates a late Maastrichtian age for the uppermost part of the succession. Two sections of the overlying Faralya Formation comprise mainly planktonic foraminifera-bearing laminated micritic limestones, brecciated limestones and mudstones. Planktonic foraminiferal assemblages of the laminated micritic limestones are dominated by keeled Late Palaeocene morphotypes. The occurrence of Morozovella acuta and Globanomalina planoconica at the base of two sections suggests a Thanetian age for the deposits. The boundary between the Babadağ and Faralya formations is characterized by a stratigraphic gap ranging from the latest Maastrichtian to the earliest Selandian. The gap was linked with the first of the three main events, when ophiolite obduction and incorporation of the Köyceğiz Thrust Sheet into the Lycian allochthon occured. Cretaceous limestone clasts and foraminifers within the Thanetian calciclastic rocks of the Faralya Formation could be clues to that exposure and erosion.
\end{abstract}

Keywords: Late Cretaceous, Maastrichtian Palaeocene, Babadağ Formation, Faralya Formation, Tavas nappe, Lycian nappes, SW Turkey
GÖNCÜOĞLU, 2011), while some suggest a dual origin, which explains the root of the nappe piles originating from two basins, one located to the north of the Menderes Platform and the other located between the Menderes and the Bey Dağlar1 platforms (POISSON, 1984; OKAY, 1989; ÖZKAYA, 1990, 1991; COLLINS \& ROBERTSON, 2003; ARSLAN et al., 2013). Several names have been ascribed for the same nappe piles through the years. A brief summary of names attributed for the Tavas nappe is given in Table 1. The Tavas nappe (ŞENEL, 1997a), (the lowermost tectono-stratigraphic unit of the Lycian nappes) comprises

Table 1. Correlation of several names attributed to the Tavas nappe.

\begin{tabular}{ll}
\hline GRACIANSKY (1972) & $\begin{array}{l}\text { Karadere serie, Tekedere } \\
\text { serie, Haticeana serie }\end{array}$ \\
\hline POISSON (1977) & Boz Dağ massif \\
\hline ERAKMAN et al. (1982) & $\begin{array}{l}\text { Darıyer serie, } \\
\text { Ahat serie, } \\
\text { Haticeana serie }\end{array}$ \\
\hline KONAK et al. (1987) & Tavas unit \\
\hline OKAY (1989) & Göbecik Tepe unit \\
\hline ÖZKAYA (1990) & Tavas thrust slice \\
\hline ŞENEL et al. (1994) & Tavas nappe \\
\hline COLLINS \& ROBERTSON (1998) POURTEAU et al. (2016) & Teke Dere nappe \\
\hline COLLINS \& ROBERTSON (2003) & Teke Dere thrust sheet \\
\hline
\end{tabular}




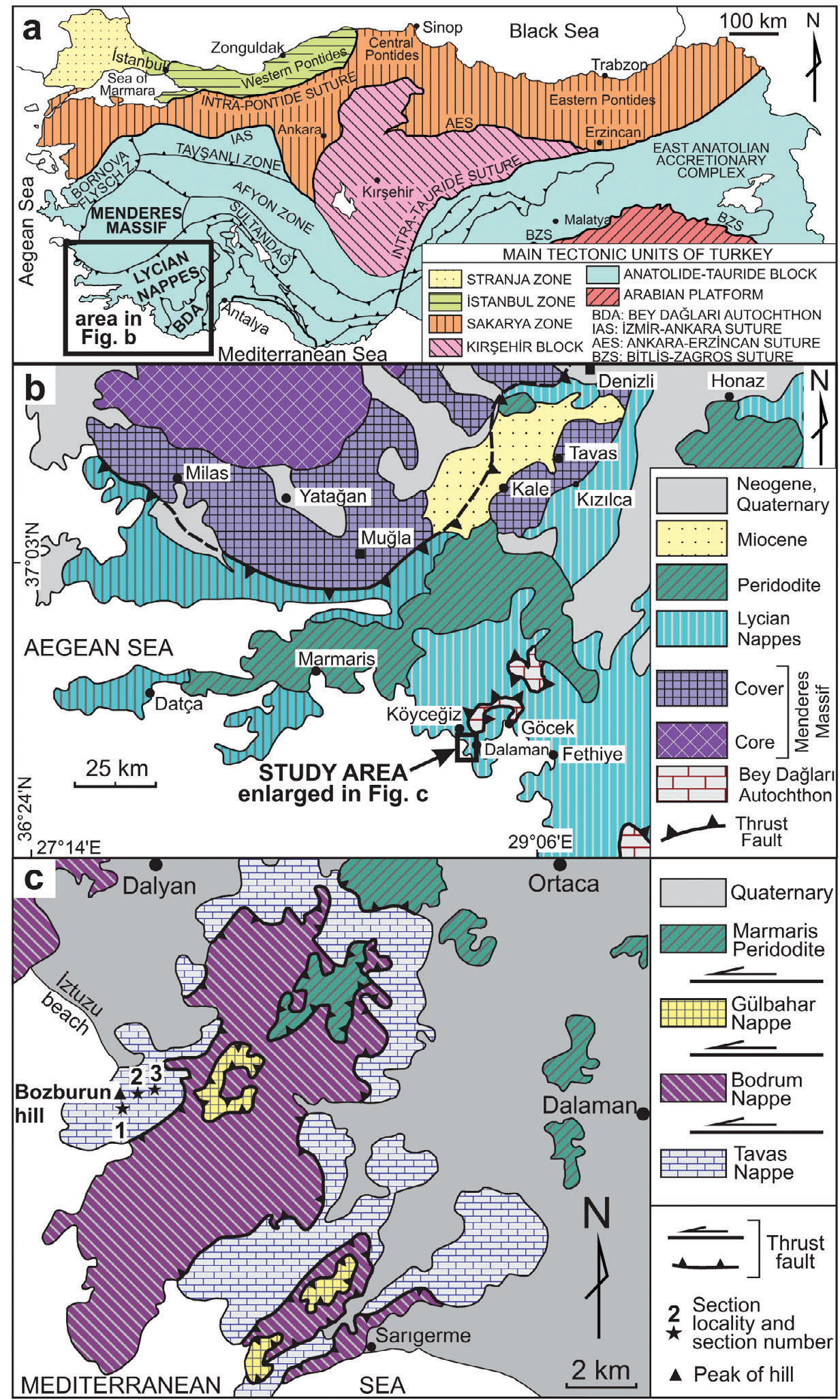

Figure 1. a) The main tectonostratigraphic zones of Turkey (after GÖRÜR \&TÜYSÜZ, 2001). Lycian nappes represents the westernmost part of the Anatolide-Tauride Block, b) Simplified geological map of SW Turkey, showing main tectonostratigraphic units and location of the study area (after ŞENEL, 1997a), c) Geological map of Bozburun hill and surroundings, showing the studied units of the Babadağ and Faralya formations and locations of the studied sections (simplified after ŞENEL, 1997a).

Upper Devonian-Norian Karadağ Serie and Upper Carboniferous-Middle Permian Tekedere Serie at the base and unconformably overlies the Rhaetian-Middle Eocene Haticeana Serie (de GRACIANSKY, 1968, 1972; ŞENEL, 1997a, b; MOIX et al., 2013). The upper part of the Tavas nappe succession is repre- sented by planktonic foraminifera-bearing uppermost Cretaceous calciturbidites (Babadağ Formation) and lower Palaeogene micritic limestones overlying flysch-type rocks (Faralya Formation) in the vicinity of Fethiye (ŞENEL, 1997a; GÜL, 2015). Similar rocks are observed to the NE of the Lycian nappes in the south 
and east of Denizli (i.e. K1zılca village and Honaz Mountain) (POISSON, 1984; OKAY, 1989) and were accepted as the deposits of the Kizilca-Çorakgöl trough (or Intra-Tauric trough) which opened between the Menderes and Bey Dağları platforms (POISSON \& SARP, 1977; POISSON, 1977; POISSON, 1984; OKAY, 1989; COLLINS \& ROBERTSON, 2003). The basin was connected with the Ionian trough (Greece) to the west according to POISSON (1984). A possible connection with the Antalya Ocean (or Pamphylia Ocean) through the north of the Isparta Angle was also claimed (POISSON, 1984; ŞENEL, 1991).

Although the uppermost Cretaceous-Lower Palaeogene successions mentioned above are important as they yield valuable palaeontological data, they have been subject to a few studies, which provide some lists of foraminifera but without illustrations (e.g. ŞENEL, 1991). The aim of this study is to document the lithostratigraphic characteristics and planktonic foraminiferal assemblages of the uppermost levels of the Babadağ Fm. and the lowermost part of the Faralya Fm. in and around Bozburun hill (south of Köyceğiz town) by the means of three measured stratigraphic sections (Fig. 1). Lithostratigraphic and depositional characteristics of the carbonate dominated rocks and planktonic foraminiferal assemblages of the successions in this locality have not been previously documented.

\section{MATERIALS AND METHODS}

This study is based on three stratigraphic sections measured from the Bozburun hill locality (Fig. 1). Planktonic foraminifera were studied in thin section as the standard washed-sample methods (hydrogen peroxide and acetic acid) did not work due to hardness of the limestones of the Babadağ Fm. and the micritic and clayey limestones of the Faralya Fm. Thin section analysis as a method has been widely used in planktonic foraminifera studies especially for the Cretaceous with a high degree of confidence (see SARI, 2009, 2013 for the literature). The position of apertures and the presence of supplementary and accessory structures which were later used for generic distinctions are not identifiable in thin section (CARON, 1985). However, most of the diagnostic criteria including the size and shape of the test, thickness of the wall, size, shape, number and arrangements of chambers, form and position of the aperture, and forms of ornamentation such as ridges, spines, the position and number of peripheral thickenings or keels can be recognized in axial and subaxial sections (section passing through or parallel to the axis of coiling) (SLITER, 1989) are usable data forms. Unfortunately, there have been a limited number of attempts to study Palaeocene planktonic foraminifera from thin section (e.g. POSTUMA, 1971; van KONIJNENBURG et al., 1998; SARI, 2013; SARIGÜL et al., 2017). The resolution of thin-section zonation is nearly as precise as zonal schemes based on isolated specimens for the Cretaceous (SLITER, 1989). The Latest Cretaceous planktonic foraminiferal zonation of the classical Tethyan Gubbio section (Italy) has recently been reviewed by COCCIONI \& PREMOLI SILVA (2015), and they also discuss several planktonic foraminiferal bioevents. The Late Cretaceous traditional zonations and bioevents developed and refined by many researchers (i.e. ROBASZYNSKI et al., 1984; CARON, 1985; SLITER, 1989; PREMOLI SILVA \& SLITER, 1994; ROBASZYNSKI \& CARON, 1995; LI \& KELLER, 1998 a, b; ROBASZYNSKI, 1998; PREMOLI SILVA \& SLITER, 1999; ROBASZYNSKI et al., 2000; PETRIZZO, 2003; PREMOLI SILVA \& VERGA, 2004; HUBER et al., 2008; PÉREZ RODRÍGUEZ et al., 2012 etc.) for almost 30 years have lately been adjusted to an updated time scale (OGG \& HINNOW, 2012; ANTHONISSEN
\& OGG, 2012). Van KONIJNENBURG et al. (1998) showed that the subdivision of the Palaeocene part of the Gran Sasso d'Italy succession (central Appennines) by thin section is nearly as precise as with isolated specimens. Palaeocene planktonic foraminiferal identification is based on van KONIJNENBURG et al. (1998), BERGGREN et al. (1995), OLSSON et al. (1999) and OLSSON et al. (2011). Biozonation of BERGGREN et al. (1995), OLSSON et al. (1999), BERGGREN \& PEARSON (2005) and OLSSON et al. (2011) adjusted to an updated timescale (VANDENBERGHE et al., 2012; ANTHONISSEN \& OGG, 2012) is followed herein. Because two dimensional axial views of some Palaeocene species in thin section can have a similar appearance, separation of these taxa is not always possible. Therefore, these species are grouped together such as the Morozovella angulata - Morozovella aequa group and Morozovella conicotruncana Morozovella velascoensis group as in SARI (2013). The other keeled Late Palaeocene taxa such as Globanomalina planoconica, Globanomalina pseudomenardii, Igorina albeari, Morozovella acuta, Morozovella acutispira, Morozovella occlusa, Morozovella pasionensis and Acarinina subsphaerica can be determined in thin section as their typical characteristics are seen in axial sections.

Thin sections were studied under an Olympus BX50 microscope and photomicrographs were taken by an Olympus E330 camera attached to the microscope. All the specimens and thin sections described and illustrated in this paper are stored in the Department of Geological Engineering of Dokuz Eylül University.

\section{GEOLOGICAL SETTING AND STRATIGRAPHY}

The nappe piles in SW Turkey, which were named as Lycian nappes by BRUNN et al. (1971) have been known since PHILIPSON's work (1915). The Lycian nappes comprise ophiolites and several tectono-stratigraphic units, which represent various environmental conditions (i.e. platform, slope and basin etc.) and were thrust on top of the para-autochthonous Bey Dağları and Menderes successions (de GRACIANSKY, 1972; ÖZGÜL, 1976; POISSON, 1977; GUTNIC et al., 1979; ŞENGÖR \& YILMAZ, 1981; ŞENEL, 1991; 1997a, b, 2007; COLLINS \& ROBERTSON, 1998; POURTEAU et al., 2016). The Lycian nappes were divided into five nappe packages by ŞENEL (1997a, b); the Tavas, Bodrum, Gülbahar, Domuzdağ, and Marmaris Ophiolite nappes in structurally ascending order (Figs. 1c, 2). They were mainly amalgamated as a result of three main successive tectonic phases including i) obduction of the Lycian ophiolites on top of the Campanian-Maastrichtian mélange and the Köyceğiz nappe, ii) thrusting on top of the Lower Eocene fore-deep, and iii) thrusting on top of the Lower Miocene fore-deep (i.e. de GRACIANSKY, 1972; GUTNIC et al., 1979; COLLINS \& ROBERTSON, 1998; POURTEAU et al., 2016). Various names were attributed to the Lycian nappe packages by different research groups and individual researchers through the years (see references in Table 1 for correlation). Different names ascribed to the Tavas nappe of ŞENEL et al. (1994) are briefly compiled in Table 1.

The Tavas nappe, the lowermost tectonostratigraphic unit of the Lycian nappes is divided into the Karadağ, Tekedere and Haticeana Serie (Fig. 2a) (de GRACIANSKY, 1972; ŞENEL, 1997a, b). The lowermost Karadağ unit consists of a Gondwana type Neotethyan platform succession ranging from the Upper Devonian to the Upper Triassic. The Upper Carboniferous-Middle Permian Tekedere succession is composed of several thrust sheets of $\mathrm{Pa}$ laeotethyan origin (MOIX et al., 2013). The Haticeana Serie unconformably overlies the Karadağ and Tekedere Serie and com- 


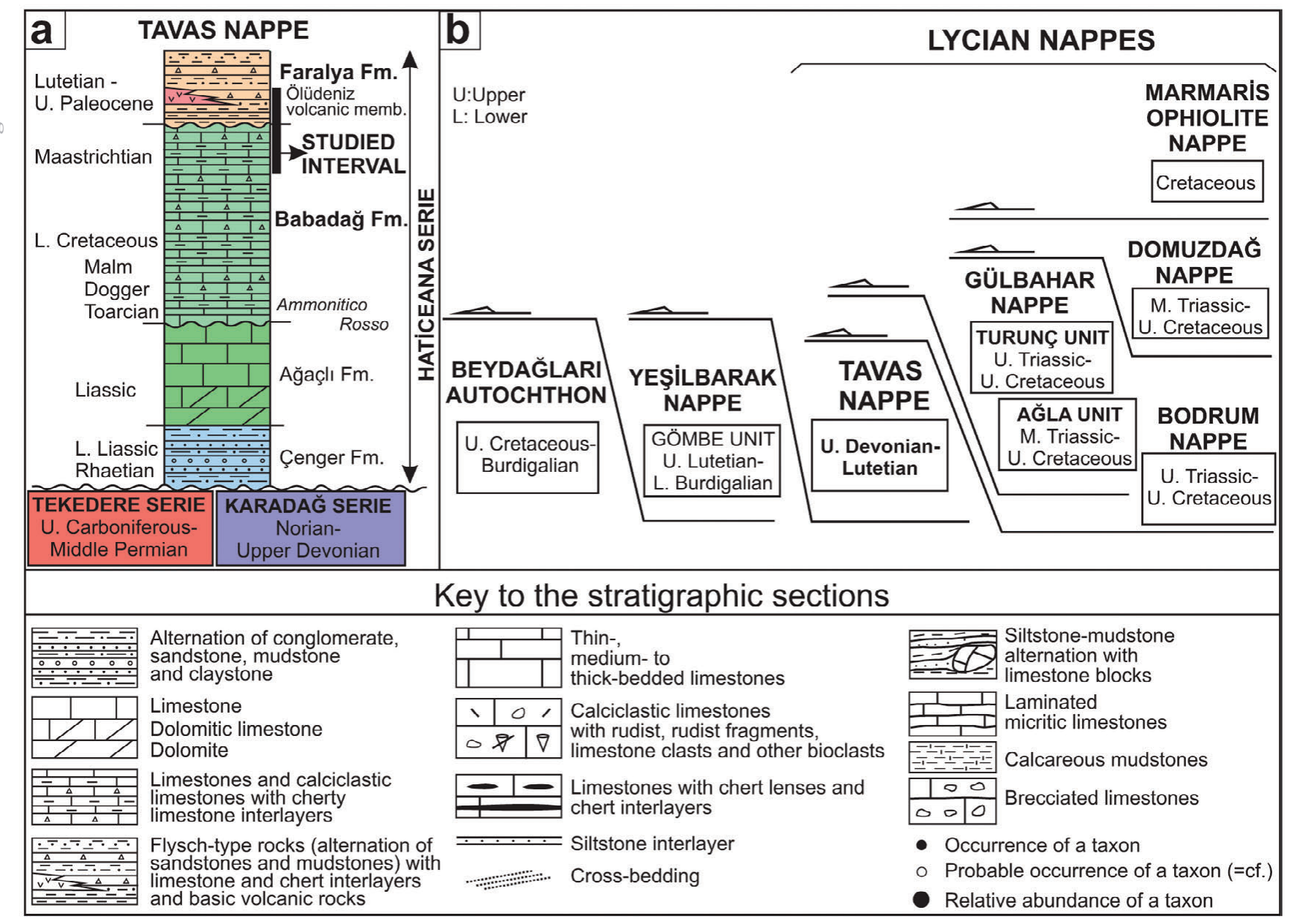

Figure 2. a) A stratigraphic column of the Tavas nappe (simplified after ŞENEL, 1997a). Studied sections correspond to the uppermost part of the Babadağ Formation and the lowermost part of the Faralya Formation (age of the Tekedere and Karadağ series is adapted from MOIX et al., 2013), b) Tectonostratigraphic positions of the nappe piles of the Lycian nappes over the relatively autochthonous units. The Tavas nappe lies at the base of these nappe packages (simplified after ŞENEL, 1997a).

prises from bottom to top, Rhaetian-lower Liassic continental clastics (Çenger Fm.), Liassic platform limestones (Ağaçlı Fm.), Toarcian-Maastrichtian cherty micritic limestones and calciturbidites (Babadağ Fm.) and Palaeocene-Lutetian (Middle Eocene) micritic limestones, basic volcanics and clastics (Faralya Fm.) (Fig. 2b) (ŞENEL, 1997a, b; SOYCAN et al., 2015). Lithostratigraphic details of the upper parts of the Babadağ Fm. and the lowermost part of the Faralya Fm. observed on the Bozburun hill locality are presented below.

\subsection{The Babadağ Formation}

The Babadağ Fm. named by ERAKMAN et al. (1982) rests on the Ağaçl $\mathrm{Fm}$. along a local unconformity surface and comprises a $650-1020 \mathrm{~m}$ thick limestone dominated succession (ŞENEL, 1997a). The unit locally includes Toarcian 'ammonitico rosso facies' at the base and is mainly represented by cherty micritic limestones and calciturbidites. The limestone succession includes local lenses of radiolarites, cherts and shales several metres thick, comprising rudist shells and fragments at the top (ŞENEL, 1997a; GÜL, 2015). Sedimentological and petrographic characteristics and controlling factors of silicification and types of cherts of the Bozburun hill locality were recently documented by GÜL (2015).

Approximately $80 \mathrm{~m}$ of the uppermost part of the Babadag Fm., made up of four lithostratigraphic levels, was examined in this study (Fig. 3). The succession has well-preserved outcrops at the top of Bozburun hill and by the roadcut to the top of the hill (Fig. 1c). The succession is dominated by light grey, whitish grey, grey, locally dark grey-coloured, medium to thick, locally thinbedded planktonic foraminifera-bearing micritic limestones (Fig. 3, Pl. 1). Calciclastic (or calciturbidite) beds (calcirudites, calcarenites and calcilutites) are intercalated with the micritic limestones. The $8 \mathrm{~m}$ thick base of the section comprises chert bands and lenses and shows widespread bioturbation (Level-1). The overlying $22 \mathrm{~m}$ (Level-2) is represented by the alternation of micritic limestones and calcarenites, which include rare coarse lithoclasts and bioclasts (i.e. rudists and corals). Level-3 is made up of $15 \mathrm{~m}$ of distinctly-bedded micritic limestones with thin siltstone interlayers and chert lenses and bands (Pl. 1a). The thickness of the chert bands and lenses ranges between 0.5 to $2.5 \mathrm{~m}$, and they are 0.2 to $3-4 \mathrm{~m}$ long.

An approximately $35 \mathrm{~m}$ thick Level-4 at the top of the section is represented by the dominance of thick calciclastic beds (mainly calcarenites and calcirudites) ( 0.5 to $1 \mathrm{~m}$ thick), which are intercalated with thin micritic limestone beds $(0.2$ to $0.3 \mathrm{~m}$ thick). Calciclastic beds include abundant limestone lithoclasts, rudist shell fragments, benthic foraminifera (Orbitoidae) and rare gastropods (Pl. 1b, c). Some of the rudist shells are complete or have well-preserved transverse sections (Pl. 1c). A rudist association comprising Hippurites cornucopiae, Biradiolites aff. cha- 
peri, Bournonia cf. fascicularis, B. cf. triangulata, Biradiolites sp., Lapeirousia sp. and Durania sp. was previouly determined in this level (ÖZER et al., 2015; ÖZER et al., 2017). H. cornucopiae within the association is known as a late Maastrichtian taxa for the Mediterranean Province (ÖZER et al., 2015; ÖZER et al., 2017).

A few large limestone lithoclast-rich interlayers are also observed within this level (Pl. 1d). Some levels comprise several limestone lithoclasts, many of which are planktonic foraminifera-bearing pelagic lithoclasts ( $\mathrm{Pl}$. 1e). These lithoclasts have sinuous boundaries with the calciclastic facies, in which they are embedded. This indicates that the two facies (i.e. planktonic foraminifera-bearing micritic facies and calciclastic facies) were both soft and not lithified during transportation. A $1 \mathrm{~m}$ thick calciclastic bed (laminated calcarenites) in the middle of this level shows low-angle cross-lamination (Pl. 1f). This bed is mainly made up of millimetre- to centimetre-sized intraclasts and skeletal debris consisting mainly of rudist fragments. This type of calciclastic beds are interpreted as proximal storm deposits (tempestites) in the literature (AIGNER, 1985; WRIGHT, 1986; FLÜGEL, 2004).

In thin section, the micritic limestones are represented by planktonic foraminifera-bearing wackestone depositional textures, which correspond to a background sedimentation in this type of calciturbidite deposits (Pl. 2a-c) (FLÜGEL, 2004). Planktonic foraminifera and other fine clasts show parallel lamination in some beds (Pl. 2b), formed as a result of transportation. Calciclastic beds are mainly represented by litho-bioclastic rudstone/ grainstone depositional textures, which are commonly associated with planktonic foraminifera (Globigerinidae)-bearing wackestones/mudstones. Carbonate lithoclasts showing various depositional textures were derived mainly from shallow water (i.e. carbonate mudstone with benthic foraminifera belonging to the family Miliolidae) and slope environments (i.e. rudstone with rudist fragments and benthic foraminifera belonging to family Orbitoidae). Planktonic foraminifera-bearing pelagic lithoclasts are also observed. Some of the lithoclasts are recrystallized. Bioclasts are mainly represented by benthic foraminifera (chiefly Orbitoidae) and rudist shell fragments (Pl. 2d, e). These types of facies correspond to the allochthonous parts of the calciturbidite deposits (FLÜGEL, 2004). The irregular and sinuous nature of the boundary between the allochthonous rudstone/grainstone facies and the planktonic foraminifera-bearing wackestone facies suggests that the two facies were not lithified but were soft during transportation. Similar calciclastic deposits were documented from the upper Campanian of the eastern Pontides by SOFRACIOGLLU \& KANDEMIR (2013) and SARI et al. (2014). This type of calciclastic deposits (i.e. calciturbidites) (BRAUNSTEIN, 1961) is typically deposited both on the slope and on the deeper sea floor at the base of the slope to basin transition (MEISCHNER, 1964; MCILREATH \& JAMES, 1984). Silt to

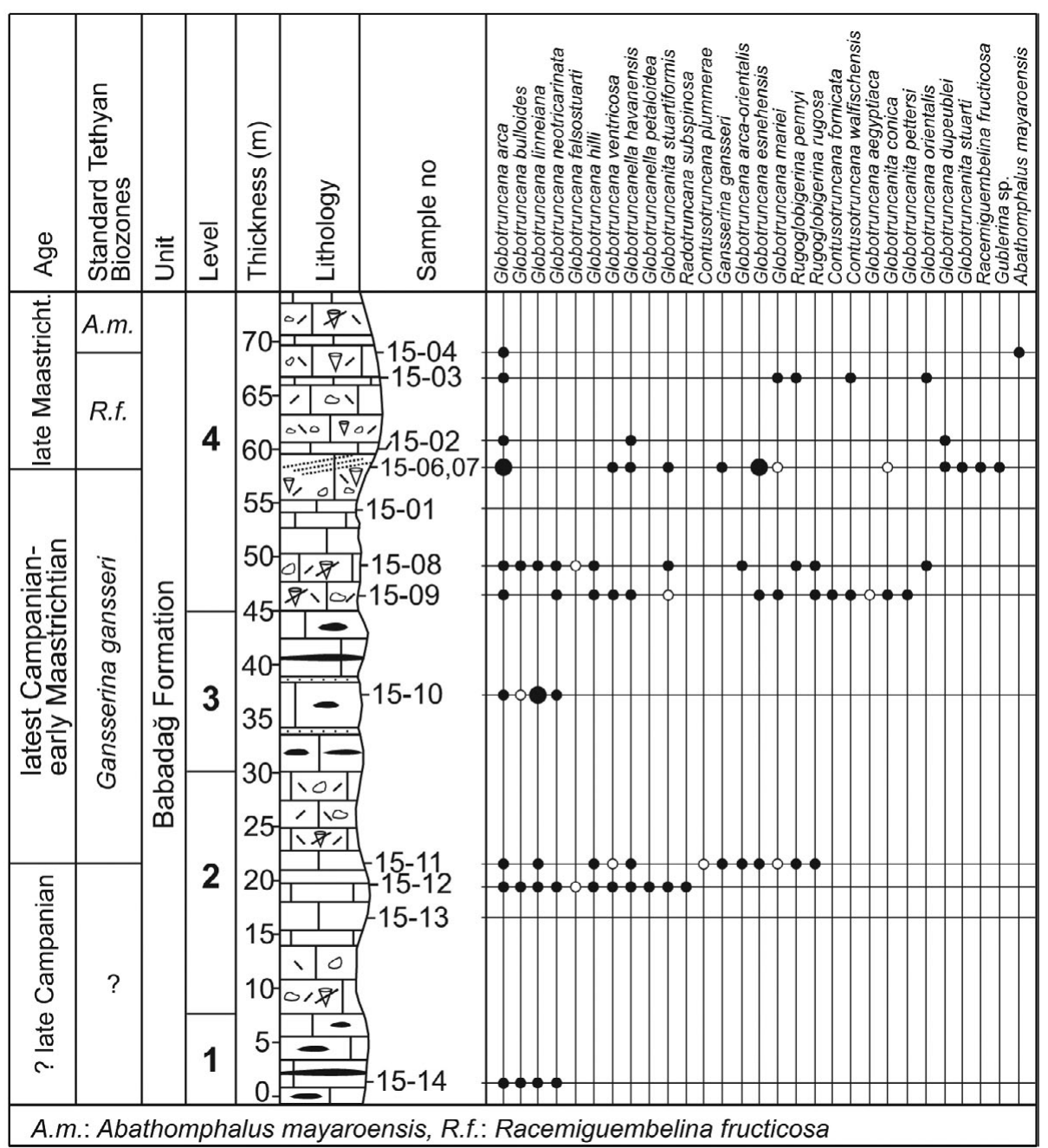

Figure 3. A stratigraphic column of the Babadağ Formation with the distribution of planktonic foraminifera in Section-1 (Coordinates; base: 35 S 0646207/4070449, top: 35 S 0646052/4070553). See Figure 2. for explanation of symbols. 
boulder size carbonate particles were derived from the shallowwater platform margin, where benthic organisms such as foraminifera (mainly Orbitoidae), rudists, corals and algae flourished. These deposits are transported down the slope by submarine debris-flows or other mass-transport mechanisms (MCILREATH \& JAMES, 1984; PAYROS \& PUJALTE, 2008).

The presence of reworked benthic organisms within the succession deposited in a deeper environment indicates that a carbonate platform persisted on a more marginal part of the late Campanian-Maastrichtian basin.

\subsection{Faralya Formation}

The formation is composed of various 'flysch-like' lithologies (i.e. micritic limestones, sandstones, breccia etc.) and basic volcanics and was named by ŞENEL et al. (1989). The lithostratigraphic characteristics and the lateral and vertical facies changes of the Faralya Fm. were documented in 12 stratigraphic sections by ŞENEL (1991). Eight of the sections were measured SE of Çameli (NE of Fethiye), three measured around Babadağ (SE of Fethiye) and one measured from the $\mathrm{N}$ of Kalkan (Fig. 1). According to the author, the unit ranges from the Late Palaeocene to Lutetian (Middle Eocene) in age, disconformably overlies the Babadağ Fm. (Fig. 2a) and is tectonically overlain by the Bod rum nappe (ŞENEL, 1991; 1997a, b). The thickness of the formation reaches a maximum $290 \mathrm{~m}$ (ŞENEL, 1997b). The formation consists of micritic limestones and clayey limestones (or sandy limestones and calcarenites) with local chert lenses at the base in the $\mathrm{NE}$ and SE of Fethiye. Towards the top, the formation includes basic volcanics, limestones, breccia with chert clasts, calciturbidites, sandstones, claystones, conglomerates etc., which interfinger with each other (ŞENEL, 1991; ŞENEL, 1997a, b). Details of the lithostratigraphy of the Faralya Fm. in the Bozburun hill locality have not been previously documented.

The patchy outcrops of the Faralya Fm. are observed on the eastern slope of Bozburun hill. Lithological characteristics and planktonic foraminiferal assemblages of the formation were documented by two stratigraphic sections (Figs. 1c, 4) as a composite section representing the whole formation could not be found in this locality due to the tectonically disturbed geology of the area. The succession can be divided into four different lithostratigraphic levels in Section-2 (Fig. 4). The $1.5 \mathrm{~m}$ thick lowermost part of the section (Level-1) is made up of grey-coloured medium to thick-bedded bioclastic/lithoclastic limestones, which includes planktonic foraminifera-bearing thin pelagic micritic limestone interbeds. Bioclastic/lithoclastic levels (i.e. the lowermost bed, where sample 15-17 was taken) comprise several limestone lithoclasts and bioclasts derived from the Upper Cretaceous. This level is overlain by $3 \mathrm{~m}$ of pinkish grey-coloured planktonic foraminifera-bearing laminated micritic limestones with rare chert bands (Level-2). Level-3 comprises an approximately $1 \mathrm{~m}$ thick sequence of reddish grey-pale red-coloured calcareous mudstones, with very rare planktonic foraminifera. The overlying Level-4 is represented by mudstone-siltstone alternations with limestone blocks. This part of the section does not yield planktonic foraminifera (Fig. 4).

Diverse lithoclasts and bioclasts are observed within the grainstone/packstone texture of the Level-1 (samples 15-17, 1525) (Fig. 4). Many of the abundant bioclasts were derived from the uppermost Cretaceous (i.e. benthic foraminifera belonging to the family Orbitoidae and Miliolidae, algae, corals and bryozoa). Some lithoclasts include Campanian-Maastrichtian planktonic foraminifera and other litho-bioclasts are embedded within the

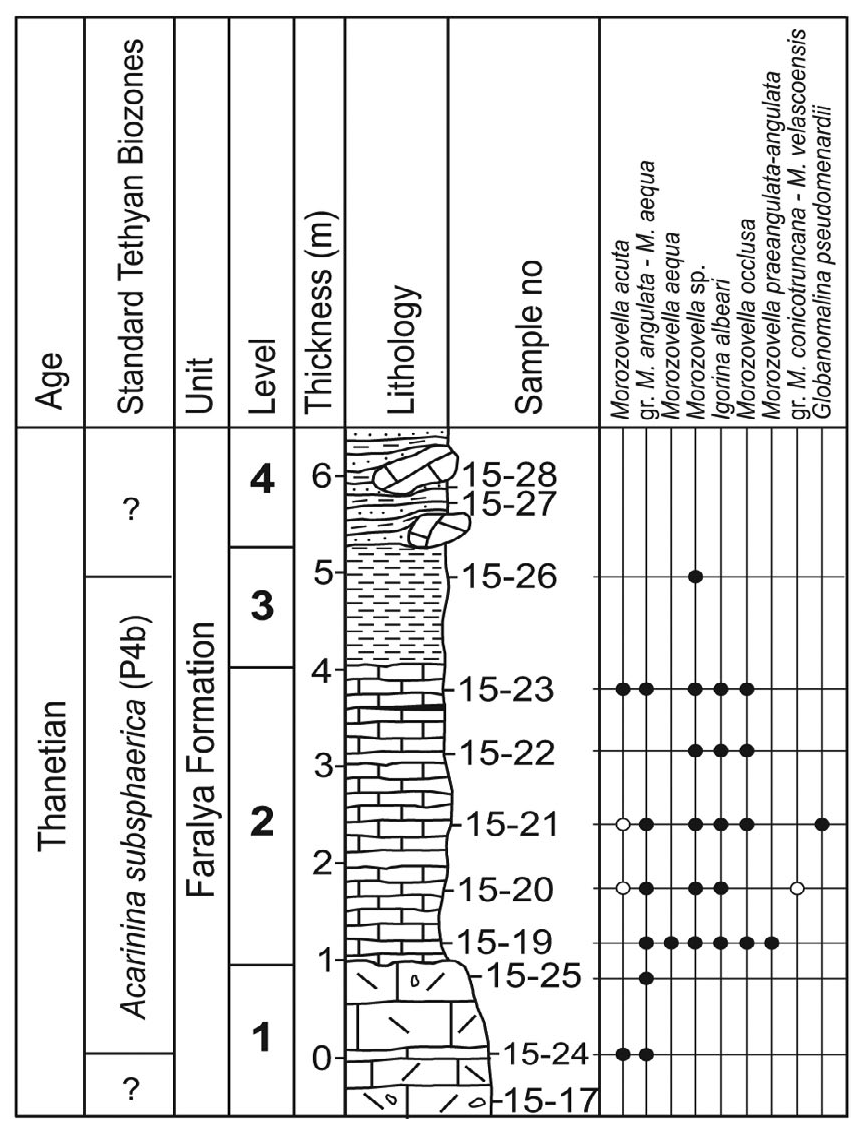

Figure 4. A stratigraphic column of the Faralya Formation with the distribution of planktonic foraminifera in Section-2 (Coordinate; 35 S 0646439/4070628). See Figure 2. for explanation of symbols.

rare Palaeocene planktonic foraminifera-bearing micrite matrix. The bed, from which sample 15-24 was taken is a thin interlayer within the litho-bioclastic limestones and comprises planktonic foraminifera-bearing wackestones, which is represented by rare but index keeled Late Palaeocene taxa. Limestones in Level-2 are dominated by planktonic foraminifera-bearing wackestone depositional textures (Fig. 4, Pl. 2f), where several Late Palaeocene taxa were identified.

The second stratigraphic section (Section-3) from the Faralya Fm. was measured some $2 \mathrm{~km}$ east of the summit of Bozburun hill along the Bozburun hill-Dalyan roadcut (Figs. 1c, 5). A $12 \mathrm{~m}$ thick part of the formation is observed in this locality, which is made up of an alternation of micritic limestones and brecciated limestones. Micritic limestone levels are represented by planktonic foraminifera-bearing wackestone depositional textures. Intercalating brecciated limestone beds show similar depositional textures with the base of the Section-2 (Level-1). The limestone clasts suggesting various depositional settings (i.e. platform, slope and basin) are embedded within the planktonic foraminifera (Palaeocene taxa)-bearing micritic matrix. Transported benthic organisms such as the latest Cretaceous foraminifera (Orbitoidae), rudist fragments, algae and corals are also observed within the matrix. The angular clasts are larger in Section-3 when compared to Section-2 and ranges up to $15 \mathrm{~cm}$ with an average of some $7-8 \mathrm{~cm}$.

These data indicate that deep marine calciclastic deposition occurred during the latest Cretaceous and prevailed in the Late Palaeocene after a sedimentary break corresponding to the Early Palaeocene. 


\subsection{Boundary between the Babadağ and Faralya formations}

The boundary between the Babadağ and Faralya formations was reported as a disconformity by ŞENEL (1991) to the NE and SE of Fethiye. The boundary between the two formations is observed in a locality, where section-2 was measured, some 800 m east of the summit of Bozburun hill (Fig. 1c). The Babadağ Fm. in this locality is represented by grey-coloured, well-bedded limestones with chert bands and angular lithoclasts. The limestones are overlain by pinkish grey-coloured friable laminated clayey limestones. The succession is cut by faults to the west and east (Fig. 6).

Cherty limestones of the Babadağ Fm. are represented by rare planktonic foraminifera-bearing wackestones with angular recrystallized intraclasts in thin section. Sample 15-16 is barren, while sample 15-15 comprises a few Campanian-Maastrichtian double-keeled globotruncanids. The assemblage includes Globotruncana cf. bulloides, G. linneiana and G. mariei, but does not yield index taxa. In the absence of any characteristic taxa, occurrences of $G$. cf. bulloides and G. linneiana in the uppermost beds of the Babadağ Fm. in that section show that at least the uppermost Maastrichtian is absent in this locality as both taxa make their last occurrences within the lower part of the Abathomphalus mayaroensis Zone (Fig. 7). The overlying laminated micritic limestones are represented by wackestones with mainly globular/ semiglobular-chambered and a few keeled Palaeocene morphotypes (sample 15-18). Two such identified taxa are Morozovella occlusa and Acarinina subsphaerica suggesting that the age of the lowermost layers of the Faralya Fm. is Late Palaeocene (Selandian-Thanetian) in the Bozburun hill locality as both taxa first appear within the P4a Zone (around middle part of Selandian) (Fig 7). Therefore, the boundary is disconformable in this locality and the time gap between the two formations corresponds to the latest Maastrichtian to the earliest Selandian.

\section{PLANKTONIC FORAMINIFERAL ASSEMBLAGES OF THE STUDIED SECTIONS}

\subsection{Section-1}

Micritic limestones of the Babadağ Fm. comprise quite diverse planktonic foraminiferal assemblages, while calciclastic beds include limited amount of taxa (Fig. 3). The planktonic foraminiferal assemblages are mainly represented by double and single keeled globotruncanids, which are associated with rare rugoglobigerinids and multiserial heterohelicids. The following taxa were observed through Section-1; Abathomphalus mayaroensis, Contusotruncana fornicata, C. cf. plummerae, C. walfischensis, Gansserina gansseri, Globotruncana cf. aegyptiaca, G. arca, G. arca-orientalis, G. bulloides, G. dupeublei, G. esnehensis, G. cf. falsostuarti, G. hilli, G. linneiana, G. mariei, G. neotricarinata, $G$. orientalis, G. ventricosa, Globotruncanella havanensis, $G l$. petaloidea, Globotruncanita conica, Gt. pettersi, Gt. stuarti, Gt. stuartiformis, Gublerina sp., Racemiguembelina fructicosa, Radotruncana subspinosa, Rugoglobigerina pennyi and R. rugosa (Fig. 3, Pl. 3). Many of the taxa identified above are classically observed within the Tethyan Campanian-Maastrichtian deposits (see papers in introduction part). The presence of $R$. fructicosa and $A$. mayaroensis within the assemblages is important as they are the nominated taxa of the $R$. fructicosa and A. mayaroensis zones of the late Maastrichtian (Figs. 3, 7) (e.g. PREMOLI SILVA \& VERGA, 2004; GRADSTEIN et al., 2012; COCCIONI \& PREMOLI SILVA, 2015). Both taxa were rarely observed in the uppermost part of the Babadağ Fm., where sample 15-06 and sam- ple 15-04 include single specimens of $R$. fructicosa and $A$. mayaroensis respectively (Fig. 3). The absence of G. bulloides and $G$. linneiana in sample 15-04 may indicate that the $10 \mathrm{~m}$ thick uppermost part of the succession corresponds to the upper part of the A. mayaroensis Zone, or may be younger as these two taxa make their last appearance within the lower part of the $A$. mayaroensis Zone (Figs. 3, 7). The occurrence of Ga. gansseri in sample 15-11 indicates that the age of this level and the limestones above should not be older than the latest Campanian, while the age of the lowermost part of the succession may be late Campanian. However, this part should not be older than the Gl. havanensis Zone as the nominated taxon of the Ra. calcarata Zone, Ra. calcarata was not observed in any samples at the base of the Babadağ succession (Figs. 3, 7).

\subsection{Section-2}

The lower part of Section-2 (Level-1) includes rare planktonic foraminifera as this part is made up of mainly calciclastic limestones (Fig. 4). Level-2 is represented by its relatively rich planktonic foraminifera content with the following taxa observed within the limestones; Globanomalina pseudomenardii, Igorina albeari, Morozovella acuta, gr. M. angulata - M. aequa, gr. cf. M. conicotruncana - M. velascoensis, M. occlusa and M. praeangulata-angulata (Fig. 4, Pl. 4). The occurrence of M. acuta in sample 15-24 suggests that the age of the lowermost part of the section is not older than the Thanetian, as the species makes its first appearance by the Selandian-Thanetian boundary (Figs. 4, 7). Other taxa such as G. pseudomenardii and I. albeari are restricted to the Selandian-Thanetian. M. occlusa makes its first

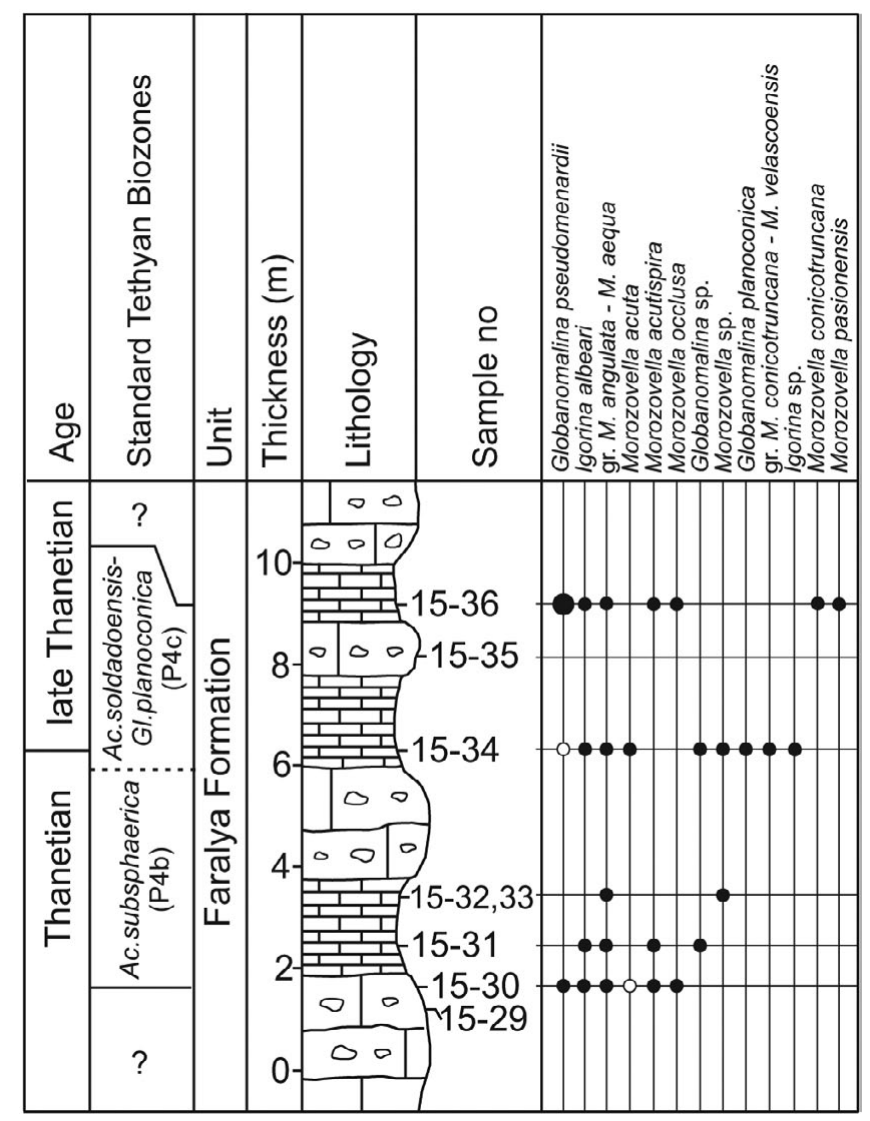

Figure 5. A stratigraphic column of the Faralya Formation with the distribution of planktonic foraminifera in Section-3 (Coordinate: 35 S 0647417/4070469). See Figure 2. for explanation of symbols. 


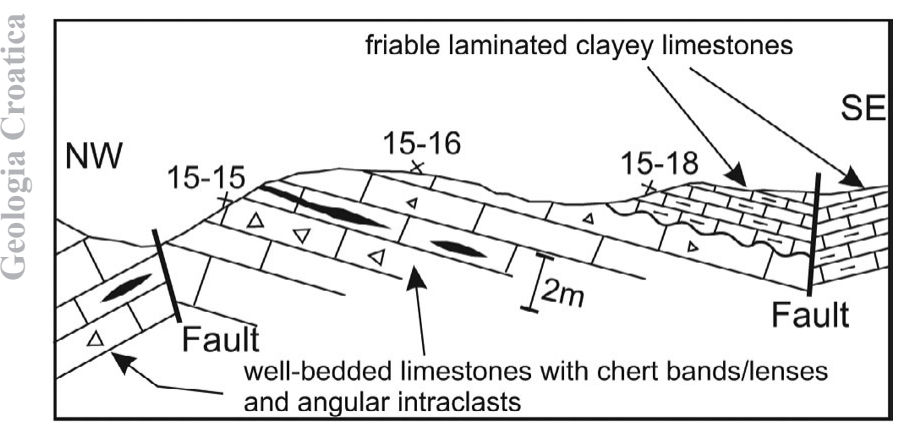

Figure 6. Cretaceous/Palaeocene boundary section, observed as a thin sequence package between two faults (Coordinates: 35 S 0646439/4070628). The boundary includes a gap ranging from the latest Maastrichtian to the earliest Selandian.

appearance at the base of the P4a Zone (middle Selandian) (BERGGREN et al., 1995; OLSSON et al., 1999; ANTHONISSEN \& OGG, 2012) (Figs. 4, 7).

\subsection{Section-3}

Micritic limestone interlayers of Section-3 yield planktonic foraminiferal assemblages, which are dominated by keeled Late Palaeocene morphotypes (Fig. 5, Pl. 5). The micritic matrix of the brecciated limestones contains rare planktonic foraminifera. The assemblages comprise G. planoconica, G. pseudomenardii, I. albeari, M. acuta, M. acutispira, gr. M. angulata-M. aequa, gr. $M$. conicotruncana-M. velascoensis, $M$. occlusa and $M$. pasionensis (Fig. 5, Pl. 5). The occurrence of $M$. cf. acuta in sample 15-30 suggests that the age of the lowermost part of the section is not older than the Thanetian as in Section-2. Likewise, the presence of G. planoconica in sample 15-34 shows that the age of the upper part of the section is late Thanetian as the species makes its first appearance within the P4c Zone (BERGGREN et al., 1995; OLSSON et al., 1999; ANTHONISSEN \& OGG, 2012) (Figs. 5, 7).

The planktonic foraminiferal assemblages observed in two sections show that the successions are more or less time equivalent. Therefore, lithological differences between them (i.e. the absence of brecciated limestones in Section-2) could be the result of lateral facies changes within the basin.

Acarinina subsphaerica and M. occlusa are observed in the lowermost limestone beds of the Faralya Fm. (Fig. 6, sample 1518). Both taxa make their first appearances close to the base of Zone P4a and M. occlusa disappears before the end of Zone P4b (BERGGREN et al., 1995; OLSSON et al., 1999; ANTHONISSEN \& OGG, 2012) (Fig. 7). Therefore the age of the lowermost layers of the Faralya Fm. is Late Palaeocene (middle Selandianmiddle Thanetian) at the Bozburun hill locality (Figs. 6, 7). Alternatively, taking into account the fact that the planktonic foraminiferal assemblages of both sections of the Faralya Fm. indicate a clear Thanetian age, the age of the lowermost beds of the formation is also Thanetian, but indicators of the Thanetian (i.e. $M$. acuta, G. planoconica etc.) were somehow not observed in the sample. In this case, the Danian and Selandian (corresponding to some 7 Ma duration of time), are missing at the Bozburun hill locality.

\section{DISCUSSION AND CONCLUSIONS}

Lithostratigraphic characteristics and planktonic foraminiferal assemblages of the upper part of the Babadağ Fm. and the lower part of the Faralya Fm. have been documented for the first time by three stratigraphic sections from the Bozburun hill locality of the Tavas nappe of the Lycian nappes.

The upper parts of the Babadağ Fm. are mainly represented by cherty micritic and calciclastic limestones. Micritic limestone beds comprise diverse planktonic foraminiferal assemblages yielding a late Campanian-Maastrichtian age. A late Maastrichtian age is obtained from the uppermost layers of the Babadag Fm., based on the presence of $R$. fructicosa and A. mayaroensis. An abundance of keeled globotruncanids ( $\mathrm{K}$-selection) within the assemblages indicates a relatively deep pelagic environment as these large, thick-walled, complex morhotypes dominate in open oceans, mainly during the onset of high sea level stands (CARON \& HOMEWOOD, 1983; ROBASZYNSI \& CARON, 1995; ABRAMOVICH et al., 2010).

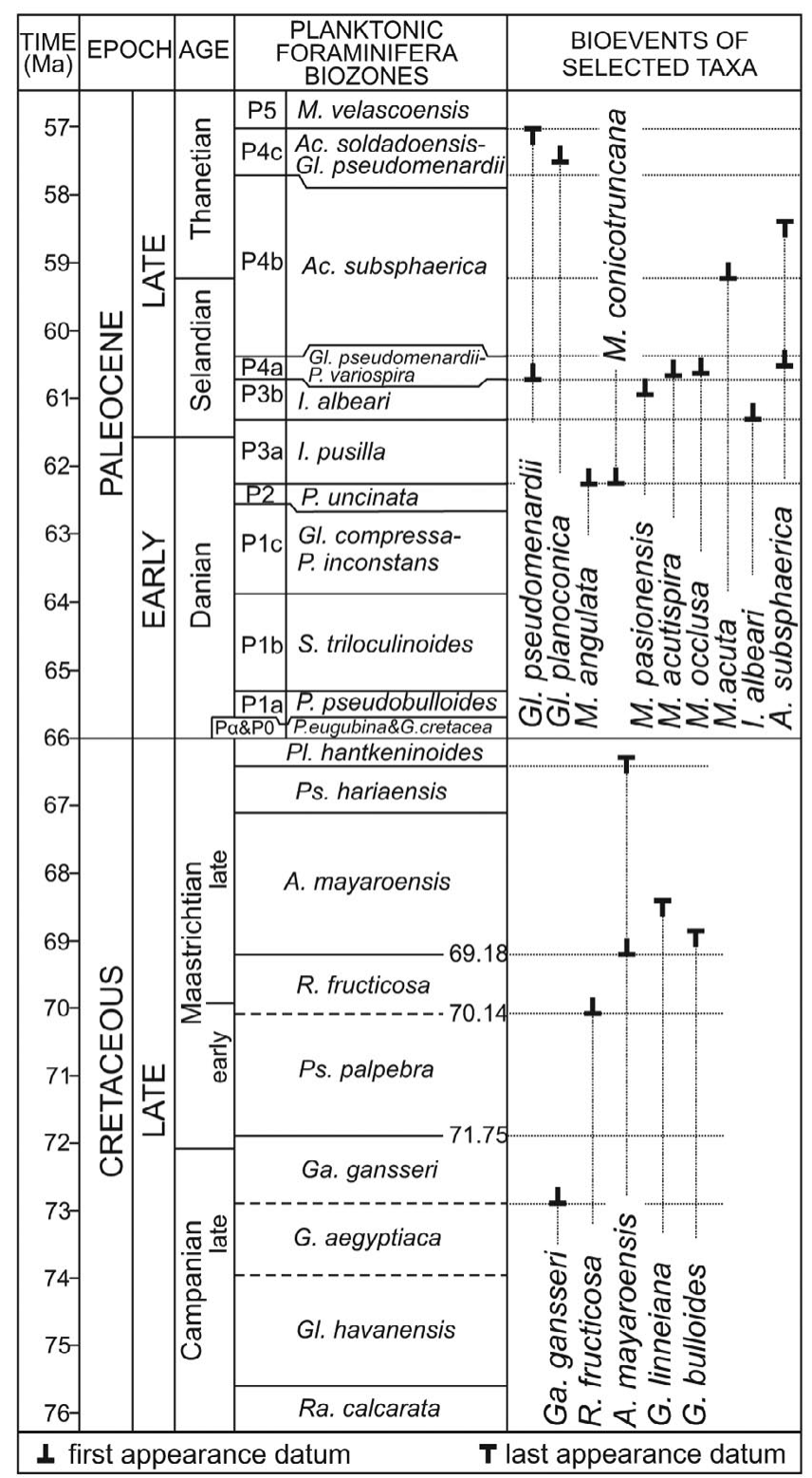

Figure 7. Latest Cretaceous-Palaeocene planktonic foraminiferal biozones and bioevents of some selected stratigraphically important taxa (first and last appearance datums) observed in this study. Numerical ages, biozones and the first and last appearance datums of the selected taxa are adapted from OGG \& HINNOW (2012) and ANTHONISSEN \& OGG (2012) (for the Upper Cretaceous) and VANDENBERGHE et al. (2012) and ANTHONISSEN \& OGG (2012) (for the Palaeocene). 
The Faralya Fm. is studied in two sections, which have different lithological properties but similar planktonic foraminiferal assemblages and ages. Section-2 is mainly made up of planktonic foraminifera-bearing wackestones with calciclastic beds at the base and mudstones with limestone blocks at the top. Section-3 is represented by the alternation of planktonic foraminifera-bearing wackestones and brecciated limestones. Planktonic foraminiferal assemblages of the two sections are dominated by keeled Late Palaeocene morphotypes. Occurrence of M. acuta at the base of Section-2 suggests that the age of the lowermost part of the section is not older that the Thanetian. Likewise, the presence of M. cf. acuta and G. planoconica at the base and top of Section-3 respectively shows that the age of the lowermost part of the section is not older that the Thanetian as in Section-2 and the age of the upper part is late Thanetian (Zones P4c or P5).

A unique section including the disconformable boundary of the Babadağ and Faralya formations at the Bozburun hill locality shows that the latest Maastrichtian to earliest Selandian rocks are absent. A gap of similar duration between two formations was also reported to the north and east of the study area ( $\mathrm{N}$ and $\mathrm{E}$ of Fethiye) by ŞENEL (1991). The latest Cretaceous-Early Palaeocene unconformity in the Tavas nappe was linked with the first of the three main tectonic events, when trench-passive margin collision caused ophiolite obduction and the Köyceğiz Thrust Sheet was incorporated into the Lycian allochthon (COLLINS \& ROBERTSON, 1998). During that time interval, the upper levels of the Lycian allochthon were subaerially exposed. The presence of eroded Cretaceous carbonates and foraminifera observed within the Thanetian calciclastic rocks as lithoclasts or bioclasts could be clues to that exposure and erosion (i.e. the base of the Section-2) (Fig. 4).

\section{ACKNOWLEDGEMENT}

This work was financially supported by a TUBITAK Grant (Project no: 113Y144), which is acknowledged. I would like to thank Sacit ÖZER and Talip GÜNGÖR for participating in the field studies and providing suggestions on the manuscript. Two anonymous reviewers and the Associated Editor Vlasta ĆOSOVIĆ are thanked for their constructive criticisms of the manuscript.

\section{REFERENCES}

ABRAMOVICH, S., YOVEL-COREM, S., ALMOGI-LABIN, A. \& BENJAMINI, C. (2010): Global climate change and planktic foraminiferal response in the Maastrichtian.- Paleoceanography, 25, PA2201. doi: 10.1029/2009PA001843

AIGNER, T. (1985): Storm depositional systems.- Lecture Notes in Earth Science, 3, 174 p., Stuttgart (Schweizerbart).

ANTHONISSEN, D.E. \& OGG, J.G. (compilers) (2012): Appendix 3: Cenozoic and Cretaceous biochronology of planktonic foraminifera and calcareous nannofossils.- In: GRADSTEIN, F.M., OGG, J.G., SCHMITZ, M.D. \& OGG, G.M. (eds.): The Geologic Time Scale 2012, Volume 2. Amsterdam, the Netherlands: Elsevier, 1083-1127.

ARSLAN, A., GÜNGÖR, T., ERDOĞAN, B. \& PASSCHIER, C.W. (2013): Tectonic transport directions of the Lycian nappes in southwest Turkey constrained by kinematic indicators.- Journal of Asian Earth Sciences, 64, 198-209. doi: 10.1016/j. jseaes.2012.12.016

BERGGREN, W.A. \& PEARSON, P.N. (2005): A revised tropical to subtropical Palaeogene planktonic foraminiferal zonation.- Journal of Foraminiferal Research, 35, 279-298.

BERGGREN, W.A., KENT, D.V., SWISHER, C.C. III \& AUBRY, M.P. (1995): A revised Cenozoic geochronology and chronostratigraphy.- In: BERGGREN, W.A., KENT, D.V., SWISHER, C.C., III, AUBRY, M.P. \& HARDENBOL, J. (eds.): Geochronology, Time Scales and Global Stratigraphic Correlation. Society for Sedimentary Geology, Special Publication, 54, 129-212. doi: 10.2110/ pec.95.04.0129

BRAUNSTEIN, J. (1961): Calciclastic and siliciclastic.- American Association of Petroleum Geologists Bulletin, 45, 2017.
BRUNN, J.H., DUMONT, J.F., DE GRACIANSKY, P.C., GUTNIC, M., JUTEAU, T., MARCOUX, J., MONOD, O. \& POISSON, A. (1971): Outline of the geology of the Western Taurides.- In: CAMPBELL, A.S. (ed.): Geology and history of Turkey. Petroleum Exploration Society of Libya: Tripoli, Libya, 225-255.

CARON, M. (1985): Cretaceous planktic foraminifera.-In: BOLLI, H.M., SAUNDERS, J.B. \& PERCH-NIELSEN, K. (eds.): Plankton Stratigraphy. Cambridge University Press, Cambridge, 17-86.

CARON, M. \& HOMEWOOD, P. (1983): Evolution of early planktic foraminifers.Marine Micropaleontology, 7, 453-462. doi: 10.1016/0377-8398(83)90010-5

COCCIONI, R. \& PREMOLI SILVA, I. (2015): Revised Upper Albian-Maastrichtian planktonic foraminiferal biostratigraphy and magnetostratigraphy of the classical Tethyan Gubbio section (Italy).- Newsletter on Stratigraphy, 48/1, 47-90.

COLLINS, A.S. \& ROBERTSON, A.H.F. (1997): Lycian mélange, southwestern Turkey: an emplaced Late Cretaceous accretionary complex.- Geology, 25, 255-258.

COLLINS, A.S. \& ROBERTSON, A.H.F. (1998): Processes of Late Cretaceous to Late Miocene episodic thrust-sheet translation in the Lycian Taurides, SW Turkey.Journal of the Geological Society London, 155, 759-772.

COLLINS, A.S. \& ROBERTSON, A.H.F. (1999): Evolution of the Lycian Allochthonous, western Turkey, as a north-facing Late Palaeozoic to Mesozoic rift and passive continental margin.- Geological Journal, 34, 107-138.

COLLINS, A.S. \& ROBERTSON, A.H.F. (2003): Kinematic evidence for Late Mesozoic-Mioecene emplacement of the Lycian Allochthonous over the Western Anatolide Belt, SW Turkey.-- Geological Journal, 38, 295-310.

ERAKMAN, B., MEŞHUR, M., GÜL, M.A., ALKAN, H., ÖZTAŞ, Y. \& AKPINAR, M. (1982): Fethiye-Köyceğiz-Tefenni-Elmal1-Kalkan arasında kalan alanın jeolojisi [Geology of the area between Fethiye-Köyceğiz-Tefenni-Elmalı-Kalkan -in Turkish]: 6th Petroleum Congress of Turkey, Ankara, 23-31.

FLÜGEL, E. (2004): Microfacies of carbonate rocks. Analysis, interpretation and application.- Springer, Berlin, Heidelberg, New York, 976 p.

GÖNCÜOĞLU, M.C. (2011): Geology of the Kütahya-Bolkardağ Belt.-MTA Bulletin, $142,223-277$

GÖRÜR, N. \& TÜYSÜZ, O. (2001): Cretaceous to Miocene Palaeogeographic evolution of Turkey: Implications for hydrocarbon potential.- Journal of Petroleum Geology, 24, 1-28. doi: 10.1111/j.1747-5457.2001.tb00664.x

GRACIANSKY de, P. C. (1968): Stratigraphie des unités superposées dans le Taurus lycien et place dans l'arc dinaro-taurique.--Mineral Research and Exploration Bulletin, 71, 42-62.

GRACIANSKY de, P. C. (1972): Recherches géologiques dans le Taurus Lycien Occidental.- Thèse Doctorat d'Etat, Université de Paris-Sud, Orsay, France, 762 p.

GRADSTEIN, F.M., OGG, J.G., SCHMITZ, M.D. \& OGG, G.M. (eds.) (2012): The geologic time scale 2012. Elsevier, $1.144 \mathrm{p}$

GUTNIC, M., MONOD, O., POISSON, A. \& DUMONT, J.F. (1979): Géologie des Taurides occidentales (Turquie).- Mémoires de la Société Géologique de France, 137, $1-112$.

GÜL, M. (2015): Occurrences of Chert in Jurassic-Cretaceous Calciturbidites (SW Turkey).- Central European Journal of Geosciences, Open Geosciences (SCIE), 7, 446-464.

HUBER, B.T., MACLEOD, K.G. \& TUR, N.A. (2008): Chronostratigraphic framework for Late Campanian-Maastrichtian sediments on Blake Nose (subtropical North Atlantic).- Journal of Foraminiferal Research, 38, 162-182.

KONAK, N., AKDENIZ, N. \& ÖZTÜRK, E.M. (1987). Geology of the south of Menderes Massif. IGCP Project no: 5, Correlation of Variscan and pre-Variscan events of the Alpine Mediterranean mountain belt, field meeting: Mineral Research and Exploration Bulletin, 42-53.

LI, L. \& KELLER, G. (1998a): Maastrichtian climate, productivity and faunal turnovers in planktic foraminifera in South Atlantic DSDP sites 525A and 521.- Marine Micropaleontology, 33, 55-86.

LI, L. \& KELLER, G. (1998b): Diversification and extinction in Campanian-Maastrichtian planktic foraminifera of Northwestern Tunisia.- Eclogae Geologicae Helvetiae, 91, 75-102.

MCILREATH, I.A. \& JAMES, N.P. (1984): Carbonate Slopes.- In: WALKER, R.G. (ed.): Facies Models, 2nd ed. Geoscience Canada Reprint Ser., 1, 245-257.

MEISCHNER, K.D. (1964): Allodapische kalke, Turbidite in Riff-nahen Sedimentationsbecken.- In: BOUMA, A.H. \& BROUWER, A. (eds.): Developments in Sedimentology, Vol. 3. Elsevier, Amsterdam, 156-191.

MOIX, P., VACHARD, D., ALLIBON, J., MARTINI, R., WERNLI, R., KOZUR, H.W. \& STAMPFLI, G.M. (2013): Palaeotethyan, Neotethyan and Huğlu-Pindos Series in the Lycian Nappes (Sw Turkey): Geodynamical implications.- In: TANNER, L.H., SPIELMANN, J.A. \& LUCAS, S.G. (eds.): The Triassic System. New Mexico Museum of Natural History and Science Bulletin, 61, 401-444.

OGG, J.G. \& HINNOV, L.A. (2012): Cretaceous.- In: GRADSTEIN, F.M., OGG, J.G., SCHMITZ, M.D. \& OGG, G.M. (eds.): The Geologic Time Scale 2012, Volume 2. Amsterdam, the Netherlands: Elsevier, 793-854. doi: 10.1016/B978-0-44459425-9.00027-5 

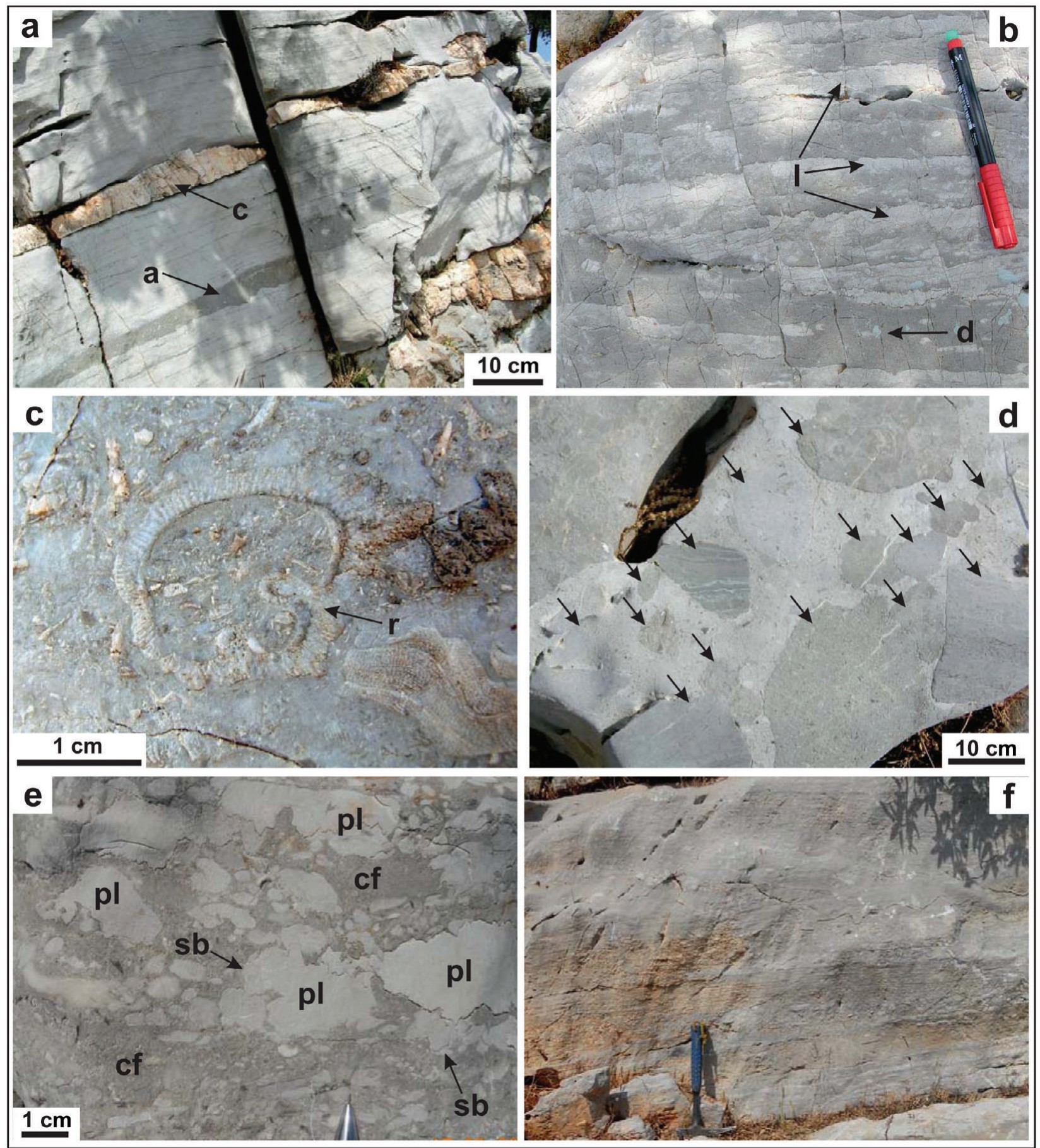

Plate I

Field views of the calciclastic limestones of the Babadağ Formation along Section-1.

a) Micritic limestones with a thin chert band (c) an allochthonous calcarenite bed (a),

b) Alternation of planktonic foraminifera-rich micritic limestone layers (I: light layers) and allochthonous lithobioclasts-rich calcarenite/calcirudite layers (d: dark layers),

c) Close-up view of a calcarenite/calcirudite bed, which is mainly composed of neritic bioclasts and lithoclasts. Complete rudist shells ( $r$ ) are also seen in these layers,

d) Close up view of a lithoclastic bed, which comprises neritic and pelagic carbonate lithoclasts (arrows) embedded within the planktonic foraminifera-bearing micritic matrix

e) A thick calciclastic bed including neritic and pelagic lithoclasts; almost all the pelagic lithoclasts ( $\mathrm{pl}$ ) have a sinuous boundary (sb) with the calciclastic facies (cf),

f) A thick calciclastic bed showing cross-bedding. 


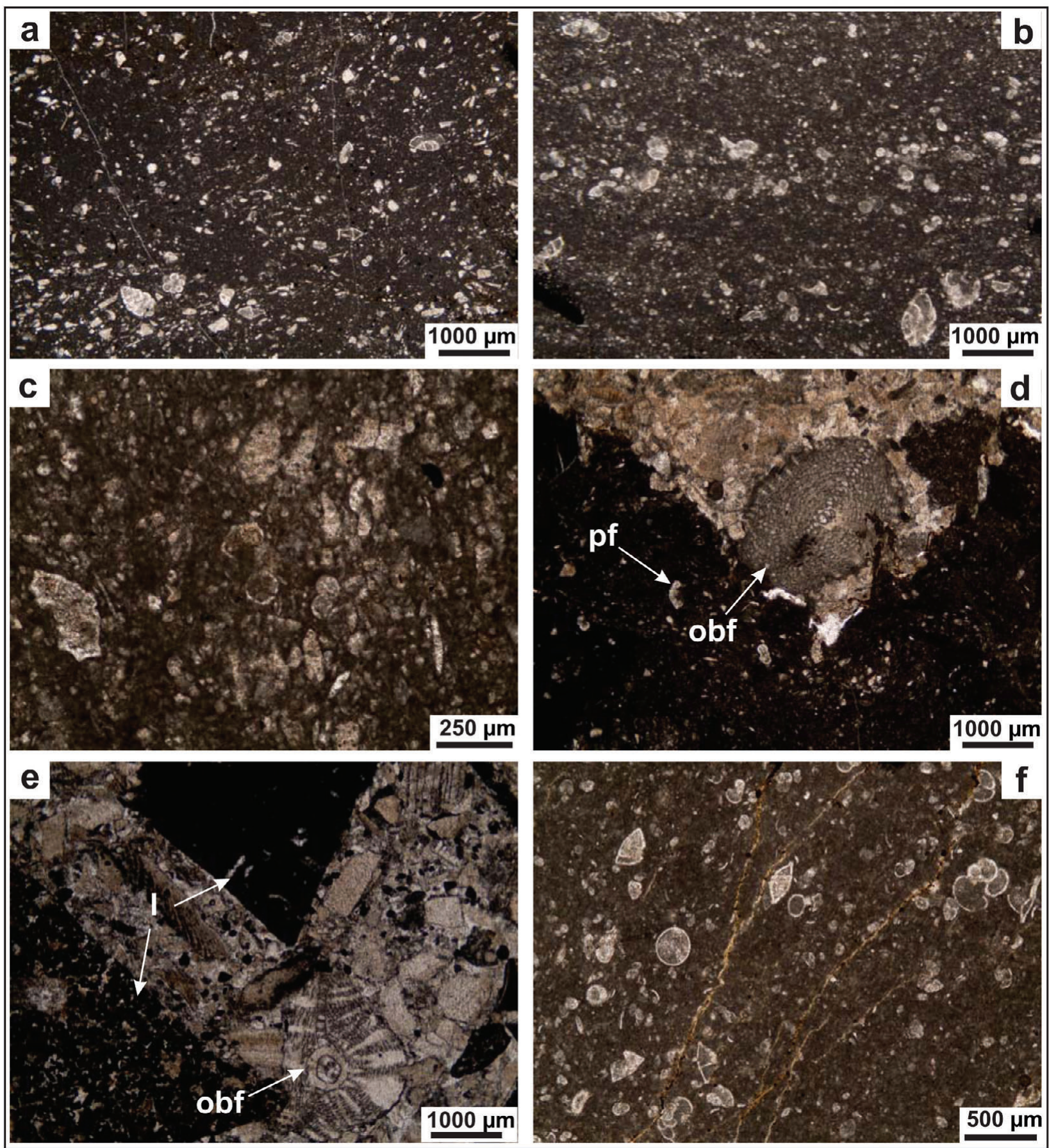

Plate II

Photomicrographs of several facies of the calciclastic and micritic limestones in the Babadağ and Faralya formations.

a) Planktonic foraminifera-rich wackestone, which is the dominant facies in the Babadağ Formation (sample 15-06),

b) Wackestone with planktonic foraminifera, showing a parallel orientation (sample 15-09)

c) Wackestone with planktonic foraminifera and fine recrystallized bioclasts (sample 15-11),

d) The contact between the wackestone/lime mudstone with rare planktonic foraminifera (pf) and the litho-bioclastic rudstone/grainstone with benthic foraminifera belonging to family Orbitoidae (obf). Note the irregular and sinuous nature of the boundary (sample 15-02),

e) Litho-bioclastic rudstone/grainstone with angular lithoclasts (I) and benthic foraminifera (Orbitoidae) (obf) (sample 15-13),

f) Wackestone with planktonic foraminifera (sample 15-20), which is the typical depositional texture of the micritic limestones of the Faralya Formation. Planktonic foraminifera are dominated by keeled Late Palaeocene morphotypes. 


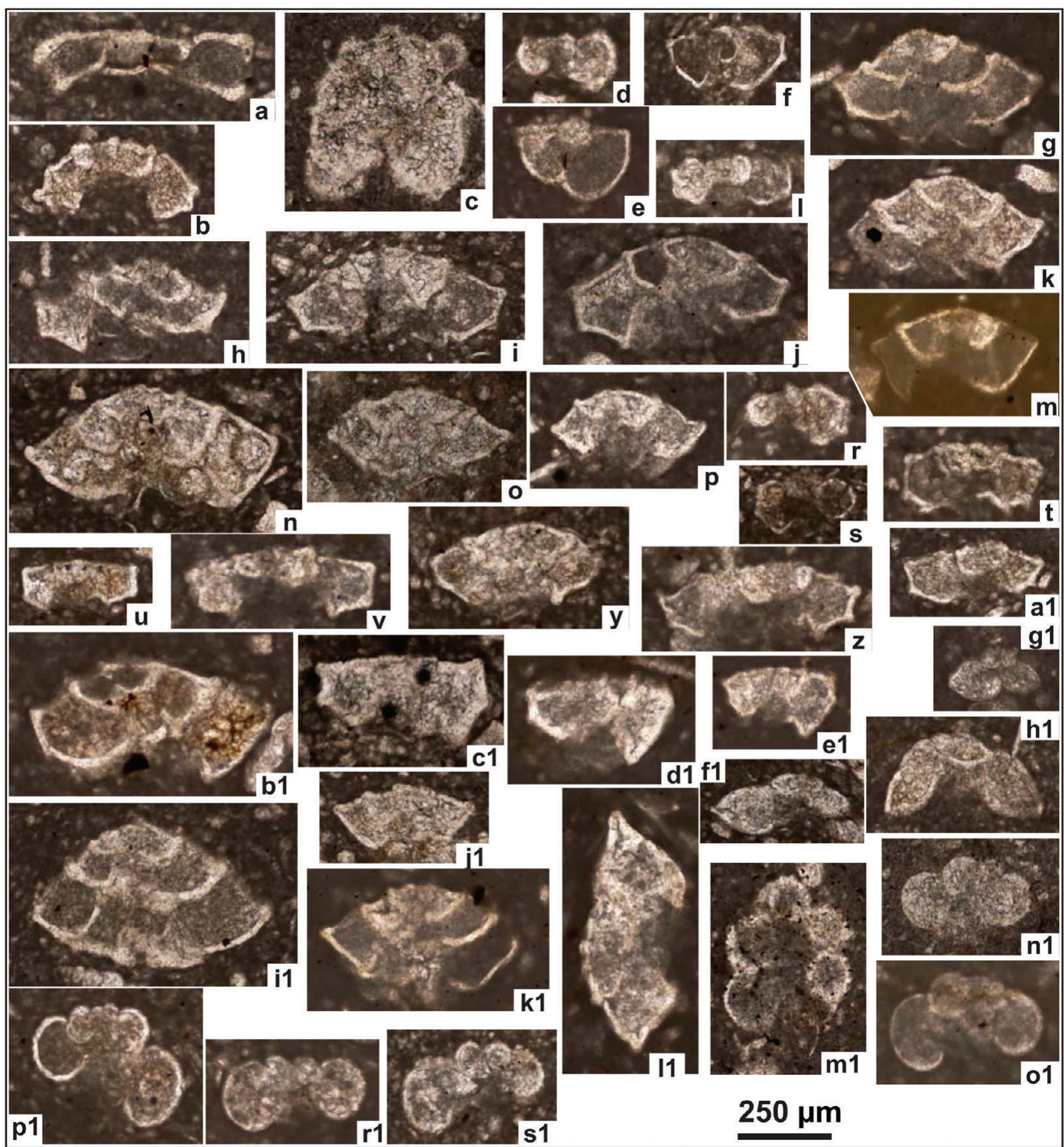

Plate III

Thin section photomicrographs of the planktonic foraminifera observed in the upper part of the Babadağ Formation along the Section-1.
a) Abathomphalus mayaroensis, sample 15-05,
o) Globotruncana esnehensis, sample 15-06a,
b) Contusotruncana fornicata, sample 15-09,
p) Globotruncana esnehensis, sample 15-06b,
c) Contusotruncana walfischensis, sample 15-03,
r) Globotruncana hilli, sample 15-08,
d) Gansserina gansseri, sample 15-11,
s) Globotruncana hilli, sample 15-11,
e) Gansserina gansseri, sample 15-06b,
f) Globotruncana aegyptiaca, sample 15-09,
g) Globotruncana arca, sample 15-06b,
h) Globotruncana arca, sample 15-02,
i) Globotruncana arca, sample 15-09,
j) Globotruncana arca, sample 15-08,
k) Globotruncana arca-orientalis, sample 15-08,
I) Globotruncana bulloides, sample 15-12,
m) Globotruncana dupeublei, sample 15-06a,
n) Globotruncana esnehensis, sample 15-06a,
t) Globotruncana linneiana, sample 15-08,
u) Globotruncana linneiana, sample 15-11,
v) Globotruncana linneiana, sample 15-15,
y) Globotruncana cf. mariei, sample 15-11,
z) Globotruncana neotricarinata, sample 15-12,
a1) Globotruncana neotricarinata, sample $15-09$,
b1) Globotruncana cf. orientalis, sample $15-08$,
c1) Globotruncana ventricosa, sample 15-12,
d1) Globotruncana ventricosa, sample 15-06b
e1) Globotruncana ventricosa, sample $15-06 \mathrm{~b}$,

f1) Globotruncanella havanensis, sample 15-08, g1) Globotruncanella havanensis, sample $15-02$, h1) Globotruncanella petaloidea, sample 15-12,

i1) Globotruncanita conica, sample 15-09,

j1) Globotruncanita pettersi, sample 15-09,

k1) Globotruncanita stuarti, sample $15-06 b$,

I1) Globotruncanita stuartiformis, sample 15-06b, m1) Racemiguembelina fructicosa, sample 15-06a,

n1) Rugoglobigerina pennyi, sample 15-03,

o1) Rugoglobigerina pennyi, sample $15-08$

p1) Rugoglobigerina pennyi, sample 15-17,

r1) Rugoglobigerina rugosa, sample $15-08$,

s1) Rugoglobigerina rugosa, sample 15-11. 

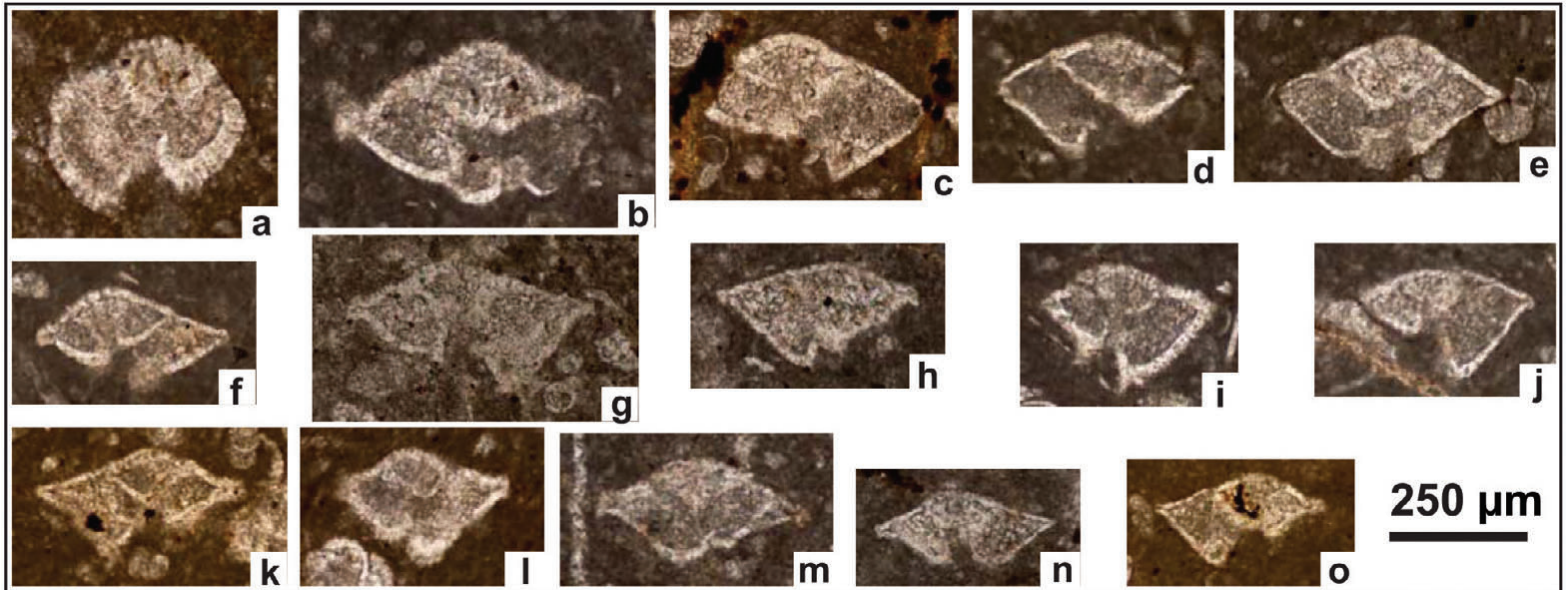

m
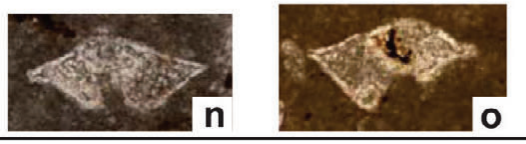

$250 \mu \mathrm{m}$

Plate IV.

Thin section photomicrographs of the planktonic foraminifera observed in the lower part of the Faralya Formation along Section-2. The planktonic foraminiferal assemblages are mainly represented by keeled Late Palaeocene morphotypes.
a) Acarinina subsphaerica, sample 15-18,
b) Igorina albeari, sample 15-20,
c) Igorina albeari, sample 15-21,
d) Igorina albeari, sample 15-21,
e) Igorina albeari, sample 15-21,
f) Igorina albeari, sample 15-23,
g) Morozovella cf. acuta, sample 15-21,
h) Morozovella cf. acuta, sample 15-20,
i) Morozovella aequa, sample 15-19,
j) Morozovella aequa, sample 15-19,
k) Morozovella occlusa, sample 15-22,
l) Morozovella occlusa, sample 15-18,
m) Morozovella occlusa, sample 15-19,
n) Morozovella occlusa, sample 15-19,
o) Morozovella occlusa, sample 15-22. 


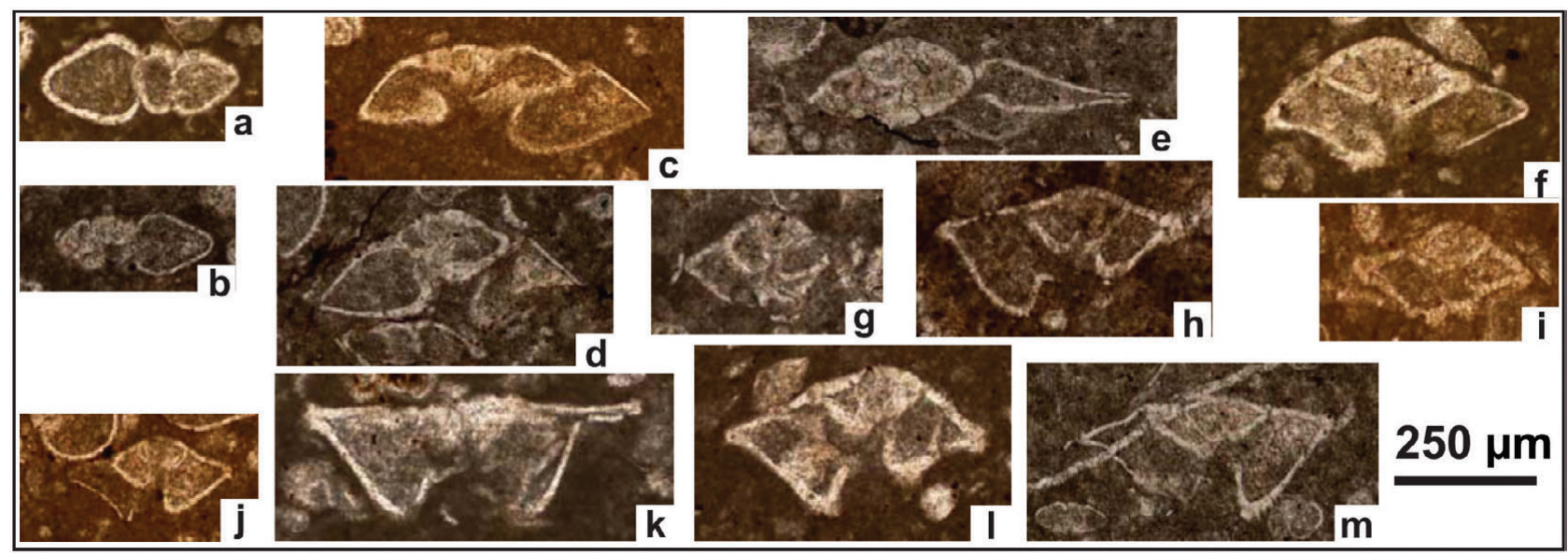

Plate V.

Thin section photomicrographs of the planktonic foraminifera observed in the lower part of the the Faralya Formation along Section-3. The planktonic foraminiferal assemblages are mainly represented by keeled Late Palaeocene morphotypes as in Section- 2 .
a) Globanomalina planoconica, sample 15-34,
b) Globanomalina planoconica, sample 15-34,
c) Globanomalina pseudomenardii, sample 15-36,
d) Globanomalina pseudomenardii, sample 15-36,
e) Globanomalina pseudomenardii, sample 15-36,
f) Igorina albeari, sample 15-36,
g) Igorina albeari, sample 15-34,
h) Morozovella cf. acuta, sample 15-30,
i) Morozovella acutispira, sample 15-31,
j) Morozovella acutispira, sample 15-36,
k) Morozovella conicotruncana, sample 15-34,
I) Morozovella occlusa, sample 15-36,
m) Morozovella pasionensis, sample 15-36. 
OKAY, A.İ. (1989): Geology of the Menderes Massif and the Lycian nappes south of Denizli, western Taurides.- Mineral Research and Exploration Bulletin, 109, $37-51$.

OKAY, A.I. \& TÜYSÜZ, O. (1999): Tethyan sutures of northern Turkey.-In: DURAND, B., JOLIVET, L., HORVATH, F. \& SERANNE, M. (eds.): The Mediterranean Basins: Tertiary extension within the Alpine oregen. Geological Society Special Publication, 156, 475-515. doi: 10.1144/GSL.SP.1999.156.01.22

OLSSON, R.K., HEMLEBEN, C., BERGGREN, W.A. \& HUBER, B.T. (1999): Atlas of Palaeocene Planktonic Foraminifera.- Smithsonian Contributions to Paleobiology, 85, 1-252.

OLSSON, R.K., HEMLEBEN, C., BERGGREN, W.A. \& HUBER, B.T. (2011): Atlas of Palaeocene planktonic foraminifera. http://services.chronos.org/foramatlas/pages/home.htm.

ÖZER, S., GÜNGÖR, T., SARI, B., SAGULAR, E.K., ÖZKAR-ÖNGEN, İ. \& GÖRMÜŞ, M. (2015): Stratigraphy of the metamorphic tectonic units of the Lycian nappes based on palaeontological data (rudist, foraminifera, nannoplankton), kinematic characteristics and comparison with the Menderes Massif and Afyon Zone. TÜBITTAK report. 263 p. (unpublished).

ÖZER, S., GÜNGÖR, T., SARI, B., SAGULAR, E.K., GÖRMÜŞ, M. \& ÖZKAR-ÖNGEN, İ. (2017): Cretaceous rudist-bearing platform carbonates from the Lycian Nappes (SW Turkey): Rudist Associations and depositional setting.- Cretaceous Research, 79, 122-145.

ÖZGÜL, N. (1976): Torosların bazı temel jeoloji özellikleri [Some geological characteristics of the Taurides-in Turkish].- Türkiye Jeoloji Kurumu Bülteni, 19, 65-78.

ÖZKAYA, İ. (1990): Origin of the allochthons in the Lycian belt, southwest Turkey.Tectonophysics, 177, 367-379.

ÖZKAYA, İ. (1991): Evolution of a Tertiary volcanogenic trough in SW Turkey - The Alakaya Basins of the Lycien Belt.- Geologische Rundschau, 80, 657-668.

PAYROS, A. \& PUJALTE, V. (2008): Calciclastic submarine fans: An integrated overview.- Earth Science Reviews, 86, 203-246. doi: 10.1016/j.earscirev.2007.09.001

PÉREZ RODRÍGUEZ, I., LEES, J.A., LARRASOANA, J.C., ARZ, J.A. \& ARENILLAS, I. (2012): Planktonic foraminiferal and calcareous nannofossil biostratigraphy and magnetostratigraphy of the uppermost Campanian and Maastrichtian at Zumaia, northern Spain.- Cretaceous Research, 37, 100-126. doi: 10.1016/j.cretres.2012.03.011

PETRIZZO, M.R. (2003): Late Cretaceous planktonic foraminiferal bioevents in the Tethys and in the Southern ocean record: an overview.- Journal of Foraminiferal Research, 23, 330-337.

PHILLIPPSON, A. (1910-1915): Reisen und Forschungen im westlichen Kleinasien. Petermanns Geographische Mitteilungen/Ergänzungsheft, 167-183.

POISSON, A. (1977): Recherches géologiques dans les Taurides occidentals (Turquie) (Ph.D. thesis): Paris-Sud (centre d'Orsay), Paris, 795 p.

POISSON, A. (1984): The extension of the Ionian trough into southwestern Turkey.- In DIXON, J.E. \& ROBERTSON, A.H.F. (eds.): The Geological Evolution of the Eastern Mediterranean, 241-249. doi: 10.1144/GSL.SP.1984.017.01.18

POISSON, A. \& SARP, H. (1977): La zone de Kızlıca-Çorakgöl-un exemple de Sillon Intra-Plate-forme a la marge externe du Massif du Menderes.- In: IZDAR, E. \& NAKOMAN, E. (eds.): Sixth colloquium on geology of the Aegean region, Ege University, İzmir, 555-564.

POSTUMA, J.A. (1971): Manual of Planktonic Foraminifera.- Elsevier Publishing Company, Amsterdam, $420 \mathrm{p}$.

POURTEAU, A., OBERHÄNSLI, R., CANDAN, O., BARRIER, E. \& VRIELYNCK, B. (2016): Neotethyan closure history of western Anatolia: a geodynamic discussion.- International Journal of Earth Sciences (Geol Rundsch), 105, 203-224. doi: 10.1007/s00531-015-1226-7

PREMOLI SILVA, I. \& SLITER, W.V. (1994): Cretaceous planktonic foraminiferal biostratigraphy and evolutionary trends from the Bottacione section, Gubbio, Italy.Palaeontographia Italica, 82, 1-89.

PREMOLI SILVA, I. \& SLITER, W.V. (1999): Cretaceous paleoceanography: Evidence from planktonic foraminiferal evolution.- In: BARRERA, E. \& JOHNSON, C.C. (eds.): The Evolution of Cretaceous Ocean-Climatic System. Geological Society of America, Special Paper, 332, 301-328. doi: 10.1130/0-8137-2332-9.301

PREMOLI SILVA, I. \& VERGA, D. (2004): Practical manual of Cretaceous planktonic foraminifera.- In: VERGA, D. \& RETTORI, R. (eds.): International School on planktonic foraminifera, $3^{\text {rd }}$ Course: Cretaceous. Universities of Perugia and Milan, Tiporafia Pontefelcino, Perugia (Italy), 283 p.

ROBASZYNSKI, F. (1998): Planktonic foraminifera-Upper Cretaceous, Chart of Cretaceous Biochronostratigraphy.- In: de GRACIANSKY, P.C., HARDENBOL, J. \& VAIL, P.R. (eds.): Mesozoic and Cenozoic sequence stratigraphy of European basins. Society For Sedimentary Geology (SEPM), Special Publication, 60, 782 p.
ROBASZYNSKI, F. \& CARON, M. (1995): Cretaceous planctonic foraminifera: comments on the Europe-Mediterranean zonation.- Bulletin de la Société Géologique de France, 166, 681-692.

ROBASZYNSKI, F., CARON, M., GONZALES DONOSO, J.M. \& WONDERS, A.A.H. (1984): Atlas of Late Cretaceous Globotruncanids.- Revue de Micropaleontologie, 26, 145-305.

ROBASZYNSKI, F., GONZALES DONOSO, J.M., LINARES, D., AMEDRO, F., CARON, M., DUPUIS, C., DHONDT, A.V. \& GARTNER, S. (2000): Le Crétacé supérieur de la région de Kalaat Senan, Tunisie centrale. Litho-biostratigraphie intégrée: zones d'ammonites, de foraminifères planctoniques et de nannofossiles du Turonien supérieur au Maastrichtien.- Bulletin des Centres de Recherches Exploration-Production Elf-Aquitaine, 22, 359-490.

SARI, B. (2009): Planktonic foraminiferal biostratigraphy of the Coniacian-Maastrichtian sequences of the Bey Dağları Autochthon, western Taurides, Turkey: Thin section zonation.- Cretaceous Research, 30/5, 1103-1132.

SARI, B. (2013): Late Maastrichtian-late Palaeocene planktic foraminiferal biostratigraphy of the matrix of the Bornova Flysch Zone around Bornova (İzmir, western Anatolia, Turkey).- Turkish Journal of Earth Sciences, 22, 143-171.

SARI, B., KANDEMIR, R., ÖZER, S., WALASZCZYK, I., GÖRMÜŞ, M., DEMIRCAN, H. \& YILMAZ, C. (2014): Upper Campanian calciclastic turbidite sequences from the Hacimehmet area (eastern Pontides, NE Turkey): integrated biostratigraphy and microfacies analysis.- Acta Geologica Polonica, 64/4, 393-418.

SARIGÜL, V., HAKYEMEZ, A., TÜYSÜZ, O., CAN GENÇ, Ş., YILMAZ, İ.Ö. \& ÖZCAN, E. (2017): Maastrichtian-Thanetian planktonic foraminiferal biostratigraphy and remarks on the K-Pg boundary in the southern Kocaeli Peninsula (NW Turkey).-Turkish Journal of Earth Sciences, 26, 1-29.

SLITER, W.V. (1989): Biostratigraphic zonation for Cretaceous planktonic foraminifers examined in thin section.- Journal of Foraminiferal Research, 19, 1-19. doi: 10.2113/gsjfr.19.1.1

SOFRACIOĞLU, D. \& KANDEMIR, R. (2013): The Upper Cretaceous calciclastic submarine fan deposits in the Eastern Pontides, NE Turkey: facies architecture and controlling factors.- Turkish Journal of Earth Sciences, 22, 588-610.

SOYCAN, H., ERDOĞAN, K. \& KONAK, N. (2015). Aalenian-Early Bathonian (Middle Jurassic) radiolarian assemblages in the Tavas nappe within Lycian nappes in the western Taurides (SW Turkey): The first dating of carbonate platform drowning.- Journal of Asian Earth Sciences, 104, 3-21.

ŞENEL, M. (1991). Likya napları içindeki volkanik katkılı Paleosen-Eosen çökelleri: Faralya Formasyonu [Palaeocene-Eocene sediments with volcanics intercalation in the Lycian nappes: Faralya Formation - in Turkish].- Maden Tetkik ve Arama Dergisi, 113, 1-16.

ŞENEL, M. (1997a): 1:100.000 Ölçekli Türkiye Jeoloji Haritaları No:1 Fethiye-L7 Paftas1 [1:250 000 scale Geological maps of Turkey No:1 Fethiye L7 Sheet - in Turkish with an English Abstract].- MTA Publications, 17 p.

ŞENEL, M. (1997b): 1:250.000 Ölçekli Türkiye Jeoloji Haritaları No:2 Fethiye Paftası [1:250 000 scale Geological maps of Turkey, No:2 Fethiye Sheet - in Turkish with an English Abstract].- MTA Publications, 26 p.

SSENEL, M. (2007): Characteristic features of the Lycian nappes and their evolution. Menderes Massif colloqioum-Proceedings, Ankara, 51-55 (in Turkish with English Abstract).

ŞENEL, M., SELÇUK, H., BILGIIN, Z.R., ŞEN, M.A., KARAMAN, T., DINCÇER, M.A., DURUKAN, E., ARBAS, A., ÖRÇEN, S. \& BILLGİ, C. (1989): Çameli (Denizli)Yeşilova (Burdur)-Elmalı (Antalya) ve dolayının jeolojisi [Geology of Çameli (Denizli)-Yeşilova (Burdur)-Elmalı (Antalya) and surroundings].- Mineral Research and Exploration Institute, Report no. 9429, Ankara (unpublished).

ŞENEL, M., AKDENIZ, N., ÖZTÜRK, E.M., ÖZDEMIR, T., KADINKIZ, G., METIN, Y., ÖCAL, H., SERDAROĞLU, M. \& ÖRÇEN, S. (1994): Fethiye (Muğla)-Kalkan (Antalya) ve kuzeyinin jeolojisi [Geology of Fethiye (Muğla)-Kalkan (Antalya) and northern part].--Mineral Research and Exploration Institute, Report no. 9761, Ankara (unpublished).

ŞENGÖR, A.M.C., YILMAZ, Y. (1981): Tethyan evolution of Turkey: a plate tectonic approach.- Tectonophysics, 75, 181-241.

VANDENBERGHE, N., HILGEN, F.J. \& SPEIJER, R.P. (2012): The Palaeogene period. In: GRADSTEIN, F.M., OGG, J.G., SCHMITZ, M.D. \& OGG, G.M. (eds.): The Geologic Time Scale 2012, Volume 2. Amsterdam, the Netherlands: Elsevier, $855-921$.

VAN KONIJNENBURG, J.H., WERNLI, R. \& BERNOULLI, D. (1998): Tentative biostratigraphy of Palaeogene planktic foraminifera in thin section, an example from the Gran Sasso d'Italia (central Apennines, Italy).- Eclogae Geol. Helv., 91, 203-216.

WRIGHT, V. R. (1986): Facies sequences on a carbonate ramp: the Carboniferous limestone of South Wales.-Sedimentology, 33, 221-241. doi: 10.1111/j.1365-3091.1986. tb00533.x 
